\author{
G.A. Yessenbayeva ${ }^{1}$, D.N. Yesbayeva ${ }^{2}$, N.K. Syzdykova ${ }^{1}$, I.A. Akpanov ${ }^{1}$ \\ ${ }^{1}$ Ye.A. Buketov Karaganda State University, Kazakhstan; \\ ${ }^{2}$ Shanghai Factory-Amigo EC Technology Co., Ltd, China \\ (E-mail: esenbaevagulsima@mail.ru)
}

\title{
On the calculation of rectangular plates by the collocation method
}

\begin{abstract}
The article is devoted to the application of the collocation method to solving differential equations, which are the basis for calculating many problems of mechanics. In this article the structure of this method is presented, its main components are highlighted; its types are characterized, as well as its classical approaches. The research of the problem of rectangular plates bending is carried out by the method of collocations in this article. The collocation method, like all numerical-analytical approximate methods, has a number of advantages and disadvantages, which are also noted in this article. The article is focused mainly on mechanics, engineers and technical specialists.
\end{abstract}

Keywords: collocation method, collocation points, bending of a rectangular plate, plate deflection function, plate equilibrium equation.

A collocation method is one of the classical methods, which has been repeatedly used to solve many problems of structural mechanics. A collocation method is a method for the numerical solution of ordinary differential equations, partial differential equations and integral equations. The idea is to choose a finite-dimensional space of candidate solutions and a number of points in the domain (these points are called collocation points), and to select that solution which satisfies the given equation at the collocation points.

\section{The collocation method for solving differential equations}

The collocation method is a numerical-analytical approximate method for solving a differential equation

$$
L y(x)=f(x),
$$

where $L$ is a differential operator; $y(x)$ is a function, which satisfies the given boundary conditions at the boundaries of the interval $(a, b) ;(a, b)$ is the domain of definition of the function $y(x)$.

The solution is sought as a finite series

$$
y(x)=\sum_{m=1}^{M} A_{m} \varphi_{m}(x) .
$$

Here $\varphi_{m}(x)$ is the coordinate functions satisfying the given boundary conditions; $A_{m}$ are unknown coefficients; $M$ is the number of members of the series.

To determine the coefficients $A_{m}$, the solution (2) is substituted into the differential equation (1), which is satisfied at the points $x_{i}(i=1, \ldots, M)$, i.e. at the collocation points from the interval $(a, b)$

$$
L y\left(x_{i}\right)=\sum_{m=1}^{M} A_{m} L \varphi_{m}\left(x_{i}\right)=f\left(x_{i}\right) .
$$

As a result, we obtain the system (3) $M$ of algebraic equations. Having solved this system, we determine the unknown coefficients $A_{m}$. After determining the coefficients, the function $y(x)$ and the necessary derivatives of this function are calculated at any point of the interval $(a, b)$, as well as outside the interval. The accuracy of the solution depends on both the choice of functions $\varphi_{m}(x)$ and the choice of collocation points.

The collocation method refers to the simplest approximate methods for solving differential equations, requiring only differentiation, functions calculation, and solution of a system of equations. In contrast to the grid method, after determining unknown coefficients numerical analytical methods allow to use the methods of mathematical analysis, to differentiate, to integrate, to determine the maximum-minimum points, etc. [1] 


\section{Internal collocation method}

As mentioned above, the coefficients $A_{m}$ are chosen so that equation (1) is satisfied at the points of collocations within the domain of definition of this equation.

\section{Boundary collocation method}

For the boundaries of a complicated form, the representation of the solution in the form (2) may be useful, where the coordinate functions $\varphi_{m}(x)$ satisfy equation (1), but do not satisfy the boundary conditions. The equations for determining the coefficients $A_{m}$ are obtained from satisfying the boundary conditions at the points of the boundary $[2]$.

\section{The calculation of rectangular plates in bending by the collocation method}

Consider a rectangular plate. We take the plate deflection function in the form

$$
w(x, y)=\sum_{m=1}^{M} \sum_{n=1}^{N} A_{m n} X_{m}(x) Y_{n}(y),
$$

where $X_{m}(x), Y_{n}(y)$ are functions satisfying the boundary conditions of the plate support at the boundaries $x=0, x=a$ and $y=0, y=b$ respectively; $A_{m}$ are unknown coefficients.

We define the collocation points $x_{i}, y_{i}, i=1, \ldots, K$, where $K=M \times N$ is the number of points of collocations. $\mathrm{K}$ is equal to the number of members of the series.

The plate equilibrium equation is satisfied at the collocation points

$$
\nabla^{4} w\left(x_{i}, y_{i}\right)=\frac{q\left(x_{i}, y_{i}\right)}{D}
$$

where $D=\frac{E h^{3}}{12}$ is the cylindrical rigidity of the plate, $q$ is the intensity of the external distributed load. We substitute (4) into (5)

$$
\begin{gathered}
\sum_{m=1}^{M} \sum_{n=1}^{N} A_{m n}\left[\frac{\partial^{4} w_{m n}\left(x_{i}, y_{i}\right)}{\partial x^{4}}+2 \frac{\partial^{4} w_{m n}\left(x_{i}, y_{i}\right)}{\partial x^{2} \partial y^{2}}+\frac{\partial^{4} w_{m n}\left(x_{i}, y_{i}\right)}{\partial y^{4}}\right]= \\
=\sum_{m=1}^{M} \sum_{n=1}^{N} A_{m n}\left[X_{m}^{I V}\left(x_{i}\right) Y_{n}\left(y_{i}\right)+2 X_{m}^{\prime \prime}\left(x_{i}\right) Y_{n}^{\prime \prime}\left(y_{i}\right)+X_{m}\left(x_{i}\right) Y_{n}^{I V}\left(y_{i}\right)\right]=\frac{q\left(x_{i}, y_{i}\right)}{D} .
\end{gathered}
$$

Consider a rectangular plate, hinged on the contour, with the following dimensions $0 \leq x \leq a, 0 \leq y \leq b$.

The boundary conditions of the plate bearing are

$$
\begin{aligned}
& w(0, y)=w(a, y)=0 ; \quad M_{x}(0, y)=M_{x}(a, y)=0 \\
& w(x, 0)=w(x, b)=0 ; \quad M_{y}(x, 0)=M_{y}(x, b)=0 .
\end{aligned}
$$

From the condition that the bending moments on the contour are zero, we have

$$
\begin{gathered}
\frac{\partial^{2} w(0, y)}{\partial x^{2}}=\frac{\partial^{2} w(a, y)}{\partial x^{2}}=0 \\
\frac{\partial^{2} w(x, 0)}{\partial y^{2}}=\frac{\partial^{2} w(x, b)}{\partial y^{2}}=0 .
\end{gathered}
$$

Taking into account the boundary conditions, we accept

$$
X_{m}=\sin m \pi \frac{x}{a}, \quad Y_{n}=\sin n \pi \frac{y}{b}
$$


and obtain a solution in the form of a double series

$$
w(x, y)=\sum_{m=1}^{M} \sum_{n=1}^{N} A_{m n} \sin m \pi \frac{x}{a} \sin n \pi \frac{y}{b} .
$$

Obviously, the boundary conditions (7) are satisfied.

The system of equations for the collocation method (6) is obtained in the form [1]

or

$$
\begin{gathered}
\left(\frac{\pi}{a}\right)^{4} \sum_{m=1}^{M} \sum_{n=1}^{N} A_{m n}\left[m^{4}+2(\lambda m n)^{2}+(\lambda n)^{4}\right] \sin m \pi \frac{x_{i}}{a} \sin n \pi \frac{y_{i}}{b}=\frac{q\left(x_{i}, y_{i}\right)}{D} ; \\
i=1, \ldots, K ; \quad \lambda=\frac{a}{b}
\end{gathered}
$$

$$
\sum_{m=1}^{M} \sum_{n=1}^{N} A_{m n} C_{m n} \sin m \pi \frac{x_{i}}{a} \sin n \pi \frac{y_{i}}{b}=\frac{q\left(x_{i}, y_{i}\right)}{D} \frac{a^{4}}{\pi^{4}},
$$

where

$$
C_{m n}=m^{4}+2(\lambda m n)^{2}+(\lambda n)^{4} .
$$

Examples of the calculation of a rectangular plate with one member of the series (4) and with three members of the series (4) are given in [1]. As can be seen from these examples, the accuracy of the calculation depends on the number of members of the series and also on the ratio of the plate sides. For a square plate, the accuracy of the calculation by three series members as compared to the calculation with one series member increased about three times for both deflections and bending moments. For a rectangular plate with $\lambda=1.5$ the accuracy increased significantly only for deflections, for bending moments the accuracy changed slightly.

It is also shown in [1] that the accuracy of the calculation results depends on the choice of collocation points. It can be seen from the results of calculation that for a square plate the change of collocation points led to a certain increase in the accuracy of deflections and a decrease in the accuracy of bending moments. At the same time, the values of deflection and bending moments were greater than the exact values, while in the previous calculation their values were less than the corresponding exact values. For a rectangular plate the change in collocation points led to a certain increase in the accuracy of the deflection and a more significant increase in the accuracy of the bending moments [1].

In the case of a bending problem for a rectangular plate, the desired deflection function $w(x, y)$ can be represented as a sum

$$
w(x, y)=\sum_{m=1}^{M} A_{m} \varphi_{m}(x, y),
$$

where $A_{m}$ are the sought-for constant coefficients,

$$
\varphi_{m}(x, y)=\xi_{m}(x) \eta_{m}(y)
$$

are pre-selected functions that determine the possible deformation of the plate and satisfy all boundary conditions.

Substituting (8) into the plate equilibrium equation

$$
D \nabla^{2} \nabla^{2} w=q(x, y),
$$

where $\nabla^{2} \nabla^{2} w$ is the biharmonic operator, we get the expression

$$
\sum_{m=1}^{M} A_{m}\left[\xi_{m}^{I V}(x) \eta_{m}(y)+2 \xi_{m}^{\prime \prime}(x) \eta_{m}^{\prime \prime}(y)+\xi_{m}(x) \eta_{m}^{I V}(y)\right]=\frac{q(x, y)}{D}
$$

which is generally not satisfied for any values of the constants $A_{m}$.

We require that the expression (9) be satisfied at $M$ points $\left(x_{1}, y_{1}\right),\left(x_{2}, y_{2}\right), \ldots,\left(x_{n}, y_{n}\right)$ in the considered domain. Then from (9) we get the system of algebraic equations 


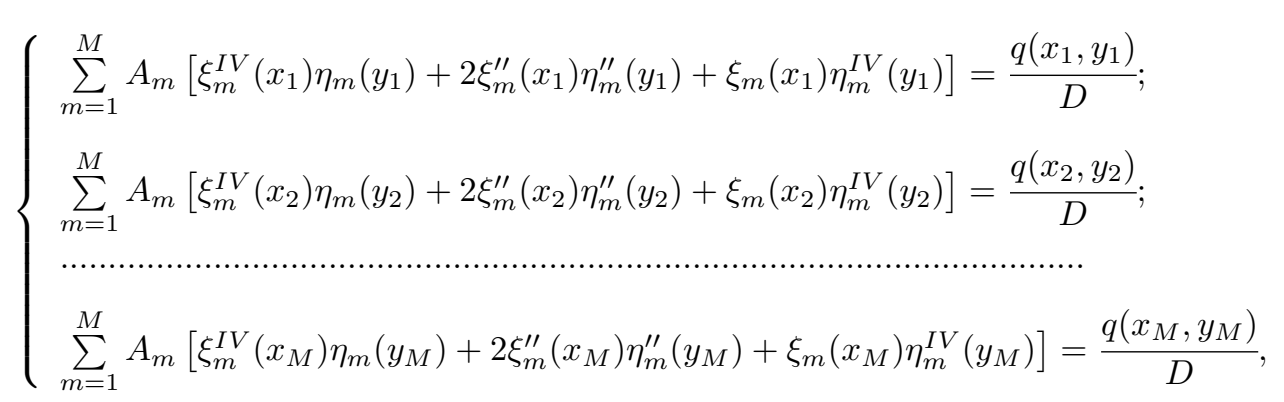

of which $M$ constants $A_{m}$ are defined.

In this case, if the selected functions $\varphi_{m}(x, y)$ do not satisfy all the boundary conditions, then in addition to the equations (10), it is necessary to write for several points of the plate contour such equations that satisfy the given boundary conditions.

For example, if the edge of the plate $x=a$ is free from fixings and loads, and the selected functions $\varphi_{m}(x, y)$ do not satisfy the conditions

$$
M_{x}(a, y)=Q_{x}(a, y)=0
$$

then for $k$ points of this edge one should write down

$$
\left\{\begin{array}{l}
M_{x}\left(a, y_{k}\right)=-D \sum_{m=1}^{M} A_{m}\left[\xi_{m}^{\prime \prime}(a) \eta_{m}\left(y_{k}\right)-\nu \xi_{m}(a) \eta_{m}^{\prime \prime}\left(y_{k}\right)\right]=0 \\
Q_{x}\left(a, y_{k}\right)=-D \sum_{m=1}^{M} A_{m}\left[\xi_{m}^{\prime \prime \prime}(a) \eta_{m}\left(y_{k}\right)+(2-\nu) \xi_{m}^{\prime}(a) \eta_{m}^{\prime \prime}\left(y_{k}\right)\right]=0
\end{array}\right.
$$

Naturally, the total number of equations of type (10) and (11) should be equal $M$, i.e. should be equal the number of constants $A_{m}$ to be determined. From this it follows that in case of an unsuccessful choice of functions $\varphi_{m}(x, y)$, the accuracy of solution of the main differential equation of the problem decreases due to the fact that in the domain occupied by the plate, it is necessary to reduce the number of collocation points.

As an example, we consider a square hinged plate loaded with a uniformly distributed load $q$. We confine ourselves to the first approximation, i.e. we keep in (8) only the first member of the series

$$
w(x, y)=A_{1} \varphi_{1}(x, y)=A_{1} \xi_{1}(x) \eta_{1}(y)
$$

For coordinate functions, we take the following expressions

$$
\left\{\begin{array}{l}
\xi_{1}(x)=x^{4}-2 a x^{3}+a^{3} x \\
\eta_{1}(y)=y^{4}-2 a y^{3}+a^{3} y
\end{array}\right.
$$

which are functions of deflections of a hinged beam of length $a$ and satisfy the given boundary conditions on the plate contour. Derivatives of these functions (12), included in the equation (10) have the form

$$
\begin{array}{ll}
\xi_{1}^{\prime \prime}(x)=12 x^{2}-12 a x ; & \eta_{1}^{\prime \prime}(y)=12 y^{2}-12 a y \\
\xi_{1}^{I V}(x)=24 ; & \eta_{1}^{I V}(y)=24 .
\end{array}
$$

We choose the collocation point in the center of the plate, i.e. we write (10)

$$
A_{1}\left[\xi_{1}^{I V}\left(x_{1}\right) \eta_{1}\left(y_{1}\right)+2 \xi_{1}^{\prime \prime}\left(x_{1}\right) \eta_{1}^{\prime \prime}\left(y_{1}\right)+\xi_{1}\left(x_{1}\right) \eta_{1}^{I V}\left(y_{1}\right)\right]=\frac{q}{D}
$$

for $x_{1}=y_{1}=a / 2$

$$
A_{1}\left(7,5 a^{4}+18 a^{4}+7,5 a^{4}\right)=\frac{q}{D},
$$

then we obtain

$$
A_{1}=0,03 \frac{q}{a^{4} D}
$$


Deflection in the center of the plate is

$$
w\left(\frac{a}{2}, \frac{a}{2}\right)=A_{1} \xi_{1}\left(\frac{a}{2}\right) \eta_{1}\left(\frac{a}{2}\right)=0,03 \frac{q}{a^{4} D} \cdot\left(\frac{5}{16} a^{4}\right)^{2}=0,00293 \frac{q a^{4}}{D} .
$$

Comparing this result with the more accurate solution $0,00406 \frac{q a^{4}}{D}$ given earlier in [3], one can see that the error is $28 \%$.

If we took a point with coordinates $x_{1}=y_{1}=a / 4$ as a collocation point, we would get

$$
A_{1}=0,048 \frac{q}{a^{4} D} ; \quad w\left(\frac{a}{2}, \frac{a}{2}\right)=0,00469 \frac{q a^{4}}{D},
$$

that is, a slightly more accurate solution with an error of $+15.5 \%$. It follows that the collocation point does not always need to be taken in the place of the least rigidity of the structure, as some researchers have recommended.

If the number of members in the row (8) increases, the accuracy of the solution naturally increases. Thus, for two terms in a series (8), for coordinate functions represented by power polynomials of type (12) and for two collocation points $x_{1}=y_{1}=a / 2$, the deflection in the center of the plate is equal to $0,00394 q a^{4} / D$, i.e. it differs from the exact solution by $3 \%$.

It can be seen that the use of the collocation method is connected, as in the variation methods, with the intuitive choice of functions. Compared to variation methods, the collocation method gives less accurate solutions with the same number of held constants. If in variation methods the error appears only when we choose approximating functions, then here, moreover, it arises when we choose collocation points.

Moreover, in the collocation method, the reciprocity of the coefficients of resolving algebraic equations is violated; as a result, these equations do not have symmetry. In addition, the collocation method is simpler than the variation methods. There is no need to integrate functions $\varphi_{i}(x, y)$ within the considered domain and, therefore, less time is required for the preparation of algebraic equations.

\title{
References
}

1 Иванов В.Н. Конспект лекций по курсу «Основы численных методов расчета конструкций»/ В.Н. Иванов. - М.: Изд-во РУДН, 2007. - 64 с.

2 Вибрации в технике: справочник: [в 6-ти т.] / ред. сов.: В.Н. Челомей (пред.). - Т. 1. Колебания линейных систем / под ред. В.В. Болотина. - М.: Машиностроение, 1978. - 352 с.

3 Аханова А.С. О расчете пластин разложением в ряд функции прогибов / А.С. Аханова, Г.А. Есенбаева, Н.К. Турсынгалиев // Вестн. Караганд. ун-та. Сер. Математика. - 2018. - № 2(82). - С. 15-22.

\section{Г.А. Есенбаева, Д.Н. Есбаева, Н.К. Сыздыкова, И.А. Ақпанов}

\section{Коллокация әдісімен тікбұрышты пластиналарды есептеу туралы}

\begin{abstract}
Мақала механиканың көптеген есептерін есептеудің негізі болып табылатын дифференциалдық теңдеулерді шешуге коллокация әдісін қолдану мәселесіне арналған. Мақалада осы әдістің құрылымы берілген, оның негізгі компоненттері көрсетілген, сондай-ақ оның түрлері мен классикалық тәсілдері сипатталған. Авторлар коллокация әдісімен тікбұрышты пластиналардың иілуі туралы есептерді зерттеді. Сондай-ақ барлық сандық-аналитикалық жуықталған әдістер сияқты коллокация әдісінің бірқатар артықшылықтары мен кемшіліктері бар екені көрсеткен. Мақала, негізінен, механиктерге, инженерлерге және техникалық мамандықтағы мамандарға бағытталған.
\end{abstract}

Kiлm сөздер: коллокация әдісі, коллокация нүктелері, тікбұрышты пластинаның иілуі, пластинаның иілу функциясы, пластинаның тепе-теңдік теңдеуі. 
Г.А. Есенбаева, Д.Н. Есбаева, Н.К. Сыздыкова, И.А. Акпанов

\section{О расчете прямоугольных пластин методом коллокаций}

Статья посвящена вопросу применения метода коллокаций к решению дифференциальных уравнений, являющихся основой расчета многих задач механики. В статье представлена структура данного метода, выделены его основные компоненты, охарактеризованы его виды, а также его классические подходы. Авторами проведено исследование задачи об изгибе прямоугольных пластин методом коллокаций. Метод коллокаций, как и все численно-аналитические приближенные методы, имеет ряд преимуществ и недостатков, которые также отмечены в данной работе. Статья ориентирована, главным образом, на механиков, инженеров и специалистов технических специальностей.

Ключевые слова: метод коллокаций, точки коллокаций, изгиб прямоугольной пластины, функция прогиба пластины, уравнение равновесия пластины.

\section{References}

1 Ivanov, V.N. (2007). Konspekt lektsii po kursu «Osnovy chislennykh metodov rascheta konstruktsii» [Lecture notes on the course «Fundamentals of numerical methods for structures calculation»]. Moscow: Izdatelstvo RUDN [in Russian].

2 Chelomey, V.N. (1978). Vibratsii v tekhnike /Vibrations in the technique]. V.V. Bolotin (Ed.). (Vol. 1-6; Vol. 1). Moscow: Mashinostroenie [in Russian].

3 Akhanova, A.S., Yessenbayeva, G.A., \& Tursyngaliyev, N.K. (2016). O raschete plastin razlozheniem v riad funktsii prohibov [On the calculation of plates by the series representation of the deflection function]. Vestnik Karahandinskoho universiteta. Seriia Matematika - Bulletin of the Karaganda University. Mathematics Series, 2 (82), 15-22 [in Russian]. 